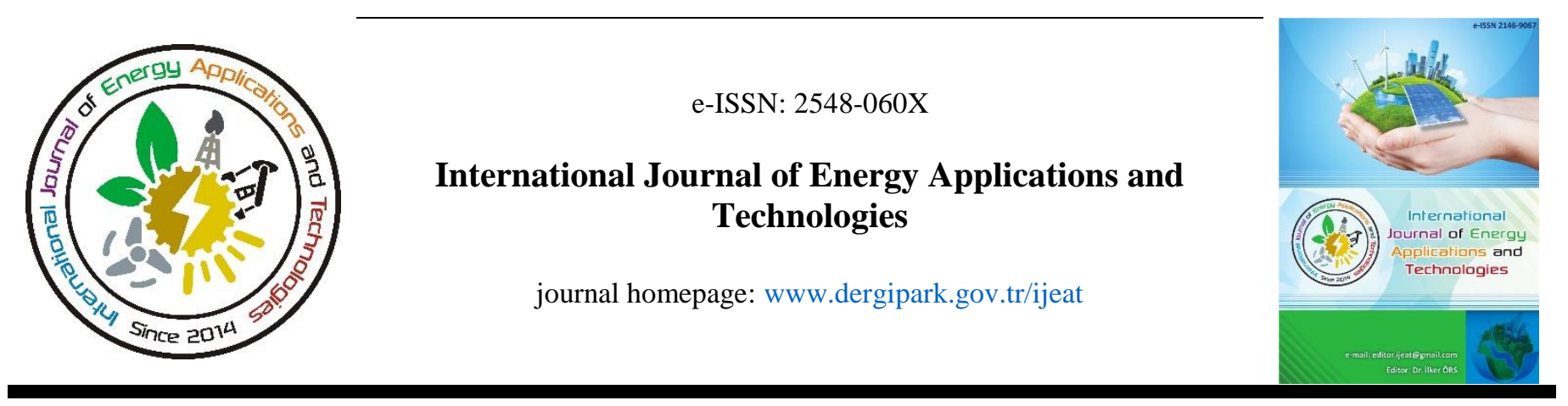

Original Research Article

\title{
Investigation of the energy (biogas) production from co-digestion of organic waste materials
}

hosted by Jurkish Oulnal Park

\author{
Patric O. Ebunilo ${ }^{1}$, Okovido John ${ }^{2}$, Aniekan E. Ikpe ${ }^{1, *}$ \\ ${ }^{1}$ Department of Mechanical Engineering, Faculty of Engineering, University of Benin, PMB 1154, Benin City, Nigeria \\ ${ }^{2}$ Department of Civil Engineering, Faculty of Engineering, University of Benin, PMB 1154, Benin City, Nigeria
}

ARTICLE INFO
* Corresponding author
ikpeaniekan@ gmail.com
Received April 20, 2018
Accepted June 11, 2018
Published by Editorial Board
Members of IJEAT
C This article is distributed by
Turk Journal Park System under
the CC 4.0 terms and conditions.

\begin{abstract}
Biogas production rate was investigated from the co-digestion of $39 \mathrm{~kg}$ each of food waste, cow dung and water; $39 \mathrm{~kg}$ each of food waste, poultry droppings and water as well as $39 \mathrm{~kg}$ each of food waste, fruit waste and water in 43 litres plastic digester setup. Although organic waste mix ratios with higher moisture content can influence decomposition rate, HRT and biogas yield, 1:1:1 mix ratio was used in this investigation. The total rate of biogas produced from the codigestion of food waste with poultry droppings and water $(39 \mathrm{~kg})$ in the ratio of 1:1:1 was 4120 $\mathrm{g}$ of raw biogas and $3700 \mathrm{~g}$ of purified biogas within with Hydraulic Retention Time 32 days, whereas, the co-digestion of food waste with cow dung and water $(39 \mathrm{~kg})$ in the same $1: 1: 1$ ratio yielded a total raw biogas of $5830 \mathrm{~g}$ and $4920 \mathrm{~g}$ of purified biogas with HRT of 35 days. However, co-digestion of food waste with fruit waster and water $(39 \mathrm{~kg})$ in the same ratio yielded a total raw biogas of $5010 \mathrm{~g}$ and purified biogas $4330 \mathrm{~g}$ with HRT of 33 days. Raw biogas produced from each organic feedstock was channelled through a scrubbing unit comprising distilled water and Type B silica gel. After the raw biogas had passed through the distilled water stream, its $\mathrm{pH}$ dropped drastically from neutral range to ultra-acidic range (7-3.2), while it also had milky color and sour taste, indicating the presence of carbonic acid $\left(\mathrm{H}_{2} \mathrm{CO}_{3}\right)$ as a result of carbon dioxide (content in the raw biogas) dissolution in the distilled water. Color of the Type B silica gel changed from crystal pink to crystal blue, indicating the absorption of water content in the biogas by silica gel particles. Organic waste is a renewable energy resource that can offset Nigeria's increasing demand for energy if harnessed and processed into cooking gas and organic fertilizers before disposal, in which case can also prevent Green House Gas (GHG) emissions into the atmosphere.
\end{abstract}

Keywords: Food waste, Co-digestion, biogas production, Renewable energy, Methane

\section{Introduction}

A number of Nigerian families, particularly in the rural areas depend mainly on traditional biomass fuel such as fire wood and charcoal [1]. Food waste is a renewable energy resource unlike fossil fuel (non-renewable energy) and the cost per Kilowatt hour (KWh) of utilising renewable energy is cheaper compared to fossil fuel [2]. However, continuous utilisation of biomass (wood fuel) in households has become a major driver of deforestation, increased biodiversity loss, depletion of wild and other natural resource base, changes in vegetation types, land degradation, climate changes [3]. Due to rapid human population in the world, high rate of consumption and urbanisation has been the result, which has led to massive increase in Municipal Solid Waste (MSW) generation [4]. Recent reports have indicated that these MSW which can salvage the increasing energy demands are piled up in various rural and urban areas in Nigerian cites without major concern about its effects or efforts to convert the waste materials into useful energy that can add value to the development of the nation, and prevent the consumption of 
wood fuel as well as its effects on the ecosystem [1]. Biogas is a mixture of gases produced from the breakdown of biodegradable waste matter, of which methane is predominant. Biogas can be produced as digested gas using anaerobic digesters or as landfill gas from landfills, which provides viable options that can suite the cravings for energy or salvage the growing energy demand in Nigeria. In recent times, studies have shown that co-digestion of organic substrates can yield a large quantity of biogas than the digestion only one type of substrate. Co-digestion of organic matter involves the digestion of multiple feed stocks of different origins such as the digestion of poultry waste with pic dung, food waste etc. [5-8]. Olmedo et al. [9] discussed that biogas has been used widely as a major source of cheap, renewable and affordable energy for domestic purpose, operating Internal Combustion Engines (ICE), power generation and gas turbines in some European countries (such as Germany, Austria, Denmark, Sweden), United States, Hongkong etc. Moreover, countries such as China, India and Nepal have used biogas for cooking for a long time and its usefulness have led to the development of standards and testing methodologies for domestic biogas stoves in China and India [10, 11]. However, there are still many countries such as Nigeria where the advancement in biogas technology is no yet available and affordable [12]. In Canada, heartland landfill yields about 18 cubic meters of landfill gas per minute, which can be recovered and transported to a landfill gas utilization facility to generate approximately 12,274 MWh of electricity on yearly basis or sufficient energy for about 1600 homes [13]. Biogas can be produced from a number of biodegradable materials such as Municipal Solid Waste (MSW), domestic waste, agricultural waste, waste from agri-food industry, sewage, manure etc. and it is a renewable energy resource with calorific value half that of natural gas [14]. According to Lijun et al. [15], biogas is a type of gas (generated in an airtight system, through fermentation and breakdown of biodegradable or organic matter by anaerobic bacteria in the absence of oxygen) that contains $45-65 \%$ Methane $\left(\mathrm{CH}_{4}\right), 25-35 \%$ of Carbon dioxide $\left(\mathrm{CO}_{2}\right)$ and 10-20\% traces of moisture, elements and chemical compounds such as Hydrogen Sulphide $\left(\mathrm{H}_{2} \mathrm{~S}\right)$, Siloxane, Hydrogen $\left(\mathrm{H}_{2}\right)$ etc. Although $\mathrm{CO}_{2}$ has zero heating value for combustion in air/oxygen, biogas is still a highquality fuel gas due to methane content which can be as high as $70 \%$ in biogas produced from municipal solid wastes, making biogas a potential energy source for household consumption [9, 16]. Moreover, Methane and Hydrogen can be subjected to combustion or oxidized with oxygen to generate energy, which enables the use of biogas as fuel in turbines, domestic stoves and IC engines. However, Methane is highly poisonous in the atmosphere and contributes to global warming as it is a major Green House Gas (GHG) that is 21 times more potent than $\mathrm{CO}_{2}$ when released into the atmosphere [17-19]. Moreover, Environmental Protection Agency's Global Anthropogenic Emissions for non $\mathrm{CO}_{2}$ GHGs report shows that Nigeria is ranked $9^{\text {th }}$ position for estimated anthropogenic methane emissions in the world, with about 2.23 Million Metric Tons of Carbon Equivalent (MMTCE) of world methane emission generated in Nigerian dumpsites [20]. From the following estimations, Nigeria is obviously a potential contributor to the global methane and $\mathrm{CO}_{2}$ emission. This study is focused on the investigation of the energy content of some organic waste typically found in Nigerian dumpsites. It will also promote the diversion of organic waste from open dumpsites, thereby creating a sustainable environment and preventing GHG emissions for public health benefits.

\section{Materials and Methods}

The experimental setup comprised a bio-digester equipped with ball valves at the inlet and outlet, biogas gas extraction hose, pressure gauge (5 bar), biogas scrubbing units interconnected with plastic hoses in which gases produced as a result of substrate decomposition passed through prior to entering the gas storage vessel. As shown in Figure 1, the first scrubbing chamber contains distilled water $\left(\mathrm{H}_{2} \mathrm{O}\right)$ to absorb Carbon dioxide $\left(\mathrm{CO}_{2}\right)$ which is the primary impurity present in biogas, whereas, the second scrubbing chamber contains Type B silica gel which is moisture absorbent that absorbs and dries up moisture content present in the biogas. Deflated motorcycle tube of known mass (496 g) was mounted right after the silica gel scrubbing chamber to serve as storage vessel for the purified biogas which in the process of entering the rubber tube causes it to inflate.

\subsection{Volume of bio-digester}

To save time and cost, the vessel used as the bio-digester was purchased in the market, after which the instrumentation and pipping were fitted according to the design. To determine the volume of the bio-digester, circumference (C) taken as the distance measured around the mid-section of the bio-digester is given by equation (1);

$$
C=2 \pi r
$$

Recall that,

$$
2 \mathrm{r}=\text { Dimeter }(\mathrm{D})
$$

Volume (V) is given by equation (3);

$$
V=\pi r^{2} h
$$

Where $\mathrm{r}$ is the radius given by equation (4);

$$
r=\frac{1}{2} D=\frac{1}{2} * 318.3
$$

Applying the measured values in equations 1-4, a total 
volume of $43,000 \mathrm{~cm}^{3}$ (43 litters) was obtained for the biodigester. The aforementioned formulas and steps were also used to determine a total volume of $2,041 \mathrm{~cm}^{3}$ (2 litters) for the scrubbers, assuming all the scrubber vessels to be of the same sizes.

\begin{tabular}{|l|l|l|l|l|l|l|l|}
\hline 1 & Substrate inlet & 6 & Ball Valve outlet & 11 & Silica gel scrubber & 16 & Hose connector \\
\hline 2 & Pressure guage & 7 & Ball valve inlet & 12 & Purified biogas outlet & 17 & Motocycle tube \\
\hline 3 & Digester & 8 & Transparent hose & 13 & Wet biogas inlet & \\
\cline { 1 - 5 } 4 & Raw biogas inlet & 9 & Gate valve (raw biogas) & 14 & Dry biogas outlet \\
\cline { 1 - 5 } 5 & Substrate outlet & 10 & Water Scrubber & 15 & Gate valve (purified biogas) \\
\cline { 1 - 3 }
\end{tabular}

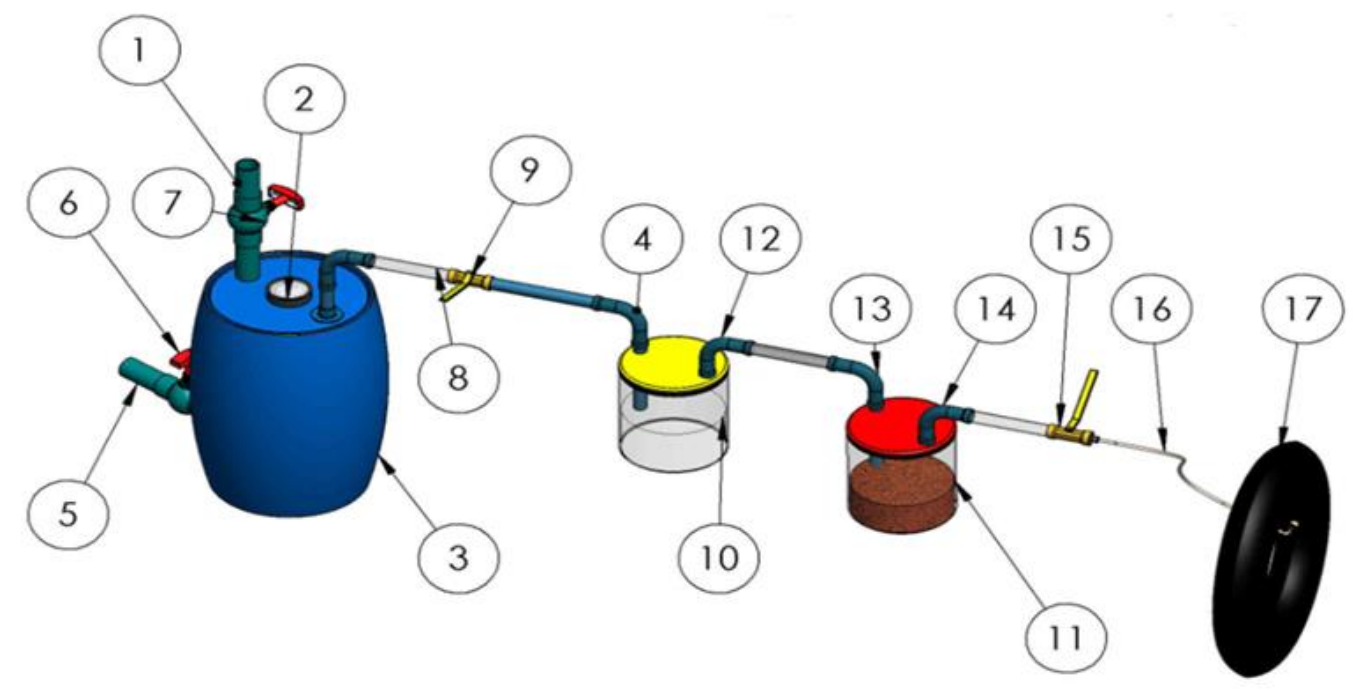

Figure 1. Experimental set-up for anaerobic digestion of organic waste

\subsection{Experimental procedure}

The experiment was carried out for three different set of organic feedstock namely; Food waste $(13 \mathrm{~kg})+$ poultry dropping $(13 \mathrm{~kg})+$ distilled water $(13 \mathrm{~kg})$; Cow dung (13 kg) + Food Waste $(13 \mathrm{~kg})+$ Distilled water $(13 \mathrm{~kg})$; and Fruit waste $(13 \mathrm{~kg})+$ Food Waste $(13 \mathrm{~kg})+$ Distilled water $(13 \mathrm{~kg})$.

- Using weighing balance, the total mass of each set of the three substrates used for the experiment were $39 \mathrm{~kg}$. Food waste used for the experiment includes Rice, Beans, Garri, Yam, Fufu, Ripe plantain, Ripe banana etc. Organic feedstocks used for the experimentation are presented in Figure 2.

- Distilled water and each set of substrate were thoroughly mixed together until the mixture became slurry.

- The distilled water and substrates mixture were poured

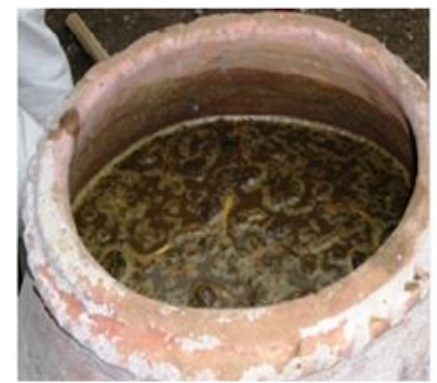

Poultry droppings

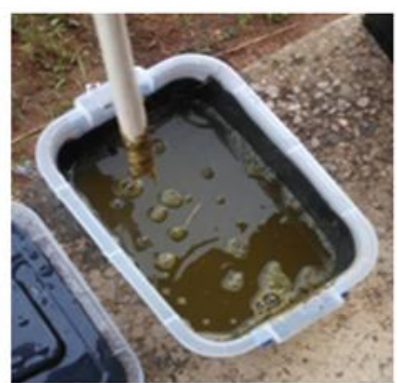

Cow dung

into the bio-digester (shown in through the inlet and after which, the digester inlet valve was closed.

- The initial gauge pressure was recorded at 0.0 bar.

- $\mathrm{pH}$ of water in the scrubbers were tested (using digital handheld $\mathrm{pH}$ meter) before and after scrubbing to determine its acidity as a result of toxic gases absorbed.

- The same procedures were applicable to all the three set of substrates introduced into the digester.

- Composition of the raw and purified biogas produced from each of the three set of substrates were determined using Optima 7 biogas handheld device. For example, the composition of raw and purified biogas produced form food waste + poultry dropping + distilled water is shown in Figure 3.

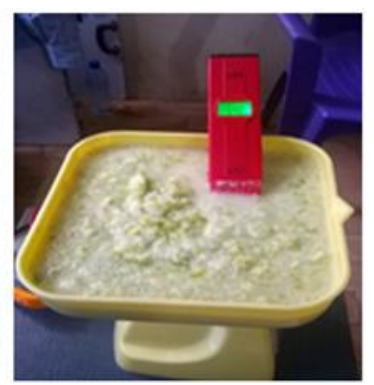

Blended fruit

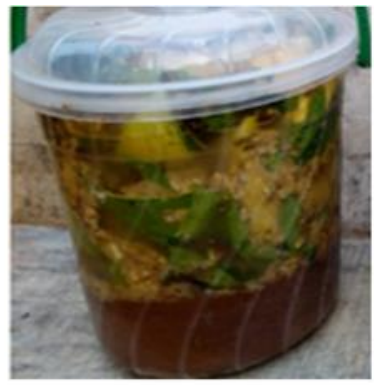

Food waste

Figure 2. Organic feedstocks used for the experimentation 
- As shown in Figure 4, the experimental setup consisted of three different units with each unit comprising of 43 liters digester, 2 liters scrubbing vessels, control valves, pressure gauge, motorcycle tube etc.

Technical specifications of the biogas analyzer and $\mathrm{pH}$ meter are presented in Table 1 as follows;

Table 1. Technical specifications of the biogas analyser and $\mathrm{pH}$ meter

\begin{tabular}{llll}
\hline Pen Type ph Meter $(\mathbf{p H}-2011)$ & Optima 7 Biogas & \\
\hline Range & $0.00-14.00 \mathrm{pH}$ & Temperature & $5^{\circ} \mathrm{C}-45^{\circ} \mathrm{C}$ \\
Resolution & $0.01 \mathrm{pH}$ & Battery & Lithium-ion Battery 6-8 Hours \\
Accuracy & $\pm 0.1 \mathrm{pH}$ & Weight & $750 \mathrm{~g}$ with 7 Sensors \\
Battery & $4 \times 1.5 \mathrm{~V}(\mathrm{AG}-13)$ & Dimension & $110 \mathrm{mmx} 225 \mathrm{~mm} 52 \mathrm{~mm}$ \\
Temperature & $0^{\circ} \mathrm{C}-50^{\circ} \mathrm{C}$ & $\mathrm{CO}_{2}$ Accuracy & $\pm 0.3 \%$ \\
Compensation & $151 \mathrm{mmx} 33 \mathrm{mmx} 20 \mathrm{~mm}$ & $\mathrm{CH}_{4}$ Accuracy & $\pm 0.3 \%$ \\
Dimension & $53 \mathrm{~g}$ & $\mathrm{H}_{2} \mathrm{~S}$ Accuracy & $\pm 5 \mathrm{ppm}$ \\
Weight & $1-6$ & Gas Flow Velocity & $1-40 \mathrm{~m} / \mathrm{s}$ \\
Acidity & $8-14$ & Power specification & $90-240 \mathrm{Vac} / 50-60$ for battery charging with \\
Alkalinity & & & USB port \\
& & Biogas Sampling Line & $3 \times 2 \mathrm{~mm}$ Viton with 5 m length and stainless \\
Neutrality & 7 & & \\
\hline
\end{tabular}

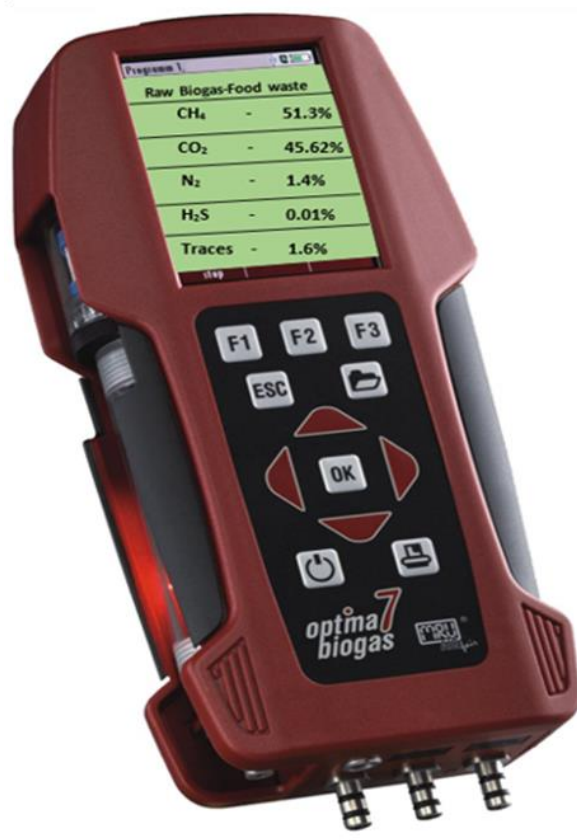

(a) Before Purification

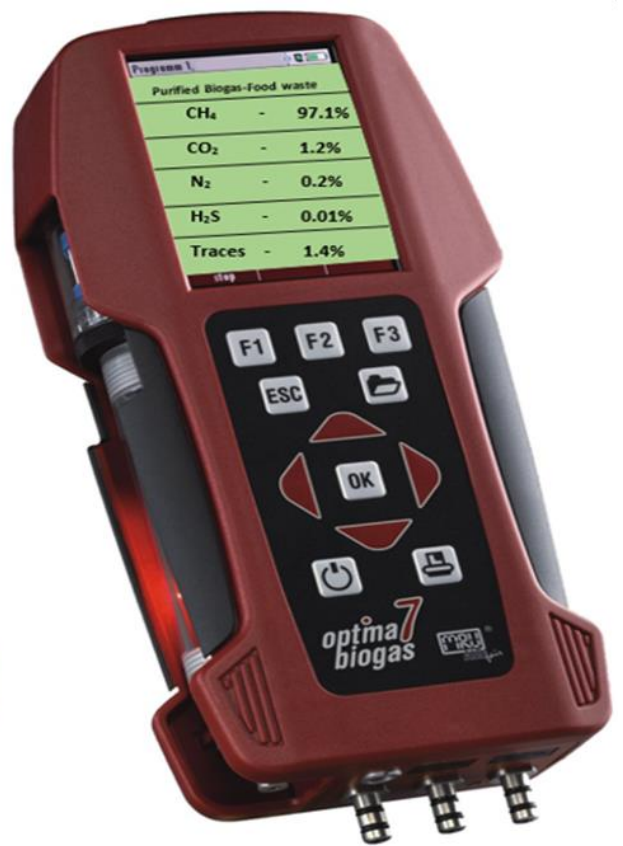

(b) After Purification

Figure 3. Optima Biogas 7 for determination of biogas composition

The main components are an infrared sensor, a sample chamber or light tube, a wavelength sample chamber, and gas concentration is measured electro-optically by its absorption of a specific wavelength in the infrared (IR). The IR light is directed through the sample chamber towards the detector. The detector has an optical filter in front of it that eliminates all light except the wavelength that the selected gas molecules can absorb. Ideally other gas molecules do not absorb light at this wavelength, and do not affect the amount of light reaching the detector to compensate for interfering components. Optima 7 Biogas analyser also comprises a Teflon filter for protection against dirt and soiling, with robust stainless steel connectors (gas ports) through which one end of a hose was connected while the other end was connected to the motorcycle tube which was used to store the biogas produced from each category of substrates. Different gas composition present in the biogas exhibited cross sensitivity in the infrared spectrum, and that enabled the percentage of individual gases in the biogas sample to be measured.

The expression of relationship between $\mathrm{pH}$ and methane yield is given by equation (5);

$$
\begin{aligned}
& \frac{\mathrm{dCH}_{4}}{\mathrm{dt}}=\left(\mathrm{Vm}_{\max } \mathrm{X}_{\mathrm{m}} \frac{\mathrm{AC}^{-1} \times 10^{-\mathrm{pH}}}{\mathrm{AC}^{-1} \times 10^{-\mathrm{pH}}+\mathrm{K}_{\mathrm{a}} \mathrm{K}_{\mathrm{m}}}\right) \times \\
& \left(\frac{\mathrm{K}_{\mathrm{im}} \mathrm{K}_{\mathrm{a}}}{\mathrm{K}_{\mathrm{im}} \mathrm{K}_{\mathrm{a}}+\mathrm{AC}^{-1} \times 10^{-\mathrm{pH}}}\right)
\end{aligned}
$$

where $\mathrm{Vm}_{\max }$ is the maximum yield rate of methane (in volume at $0^{\circ} \mathrm{C}$ and $1 \mathrm{~atm}$ pressure) per $\mathrm{g}$ of methanogenic 
bacteria per day; $\mathrm{X}_{\mathrm{m}}$-methanogenic food waste substrate $(\mathrm{g} / \mathrm{kg}) ; \mathrm{K}_{\mathrm{m}}$, Saturation constant of methane yield $(\mathrm{g} / \mathrm{kg}) ; \mathrm{K}_{\mathrm{im}}$, inhibition constant of acetate on methane yield $(\mathrm{g} / \mathrm{kg}) ; \mathrm{K}_{\mathrm{a}}$, the dissociation constant for acetate $\left(1.728 \times 10^{-5}\right)$ and $\mathrm{A}_{\mathrm{c}}$ is ionized acetate concentration $(\mathrm{g} / \mathrm{kg})$. The generalized stoichiometric reaction for the overall biogas generation is given by the expression in equation 6 ;

$$
\begin{array}{r}
C_{99} H_{149} O_{59} N \rightarrow\{50.88\} \mathrm{CH}_{4}+\{43.73\} \mathrm{CO}_{2}+ \\
\{0.85\} \mathrm{C}_{5} \mathrm{H}_{7} \mathrm{O}_{2} \mathrm{~N}+\{0.15\} \mathrm{NH}_{4}^{+}+\{0.15\} \mathrm{HCO}_{3}^{-}
\end{array}
$$

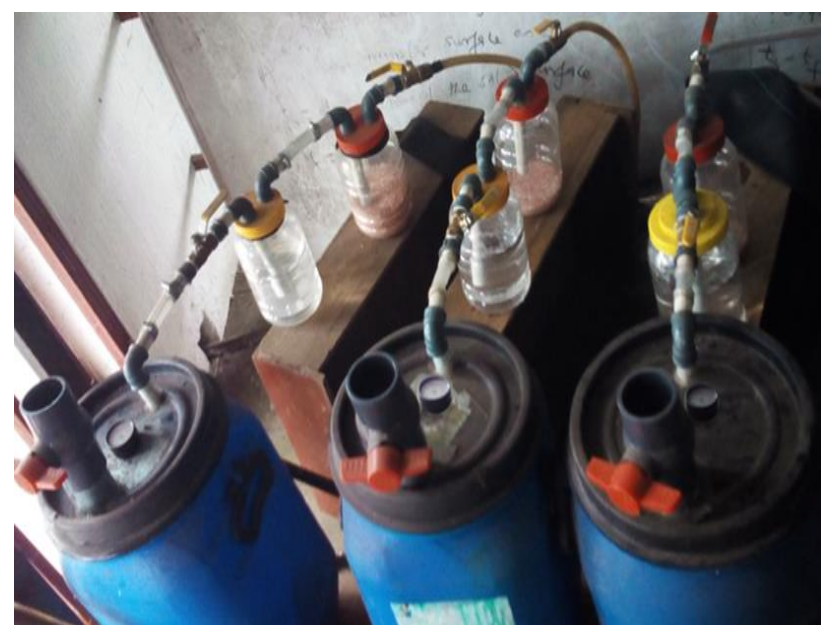

Figure 4. Experimental set-up in the laboratory

\section{Results and Discussion}

Table 2 represent different results obtained from the codigestion of food waste with poultry dropping, food waste with cow dung and co-digestion of food waste with fruit waste. Substrates ratio digested for food waste, cow dung and fruit waste were in equal proportion of $13 \mathrm{~kg}$ each, in the ratio of $1: 1: 1$ respectively.

Figure 5-7 represents biogas productivity curves plotted from co-digestion of food waste with three different categories of organic waste each (Cow dung, poultry droppings, fruit waste). Figure 8 represents the total biogas composition from Co-digestion of organic Waste Measured with Optima 7 Biogas.

As shown in Table 2, it can be observed from the results that biogas yield from the co-digestion of food waste with cow dung was comparably higher than the result of biogas yield obtained from the co-digestion of food waste with poultry dropping and result of biogas yield obtained food waste with fruit waste. However, results of biogas yield obtained from the co-digestion of food waste with fruit waste was comparably higher than results of biogas yield obtained from co-digestion of food waste with poultry dropping. Observing the trend of water acidity in terms of $\mathrm{pH}$ before and before absorbing raw biogas, there are significant variations which led to the conclusion that the more raw biogas absorbed by distilled water in the water scrubber vessel, the higher the acidity of the water and the lower the $\mathrm{pH}$ of the water.

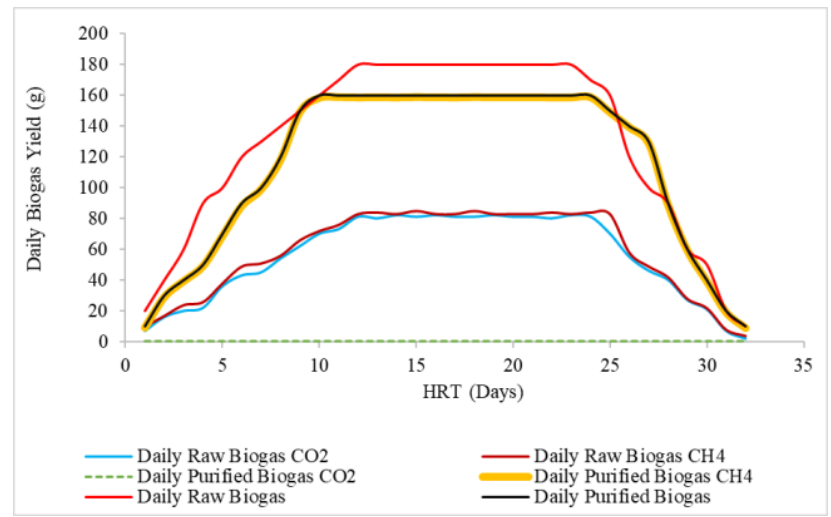

Figure 5. Biogas productivity curve plotted from codigestion of food waste with poultry droppings

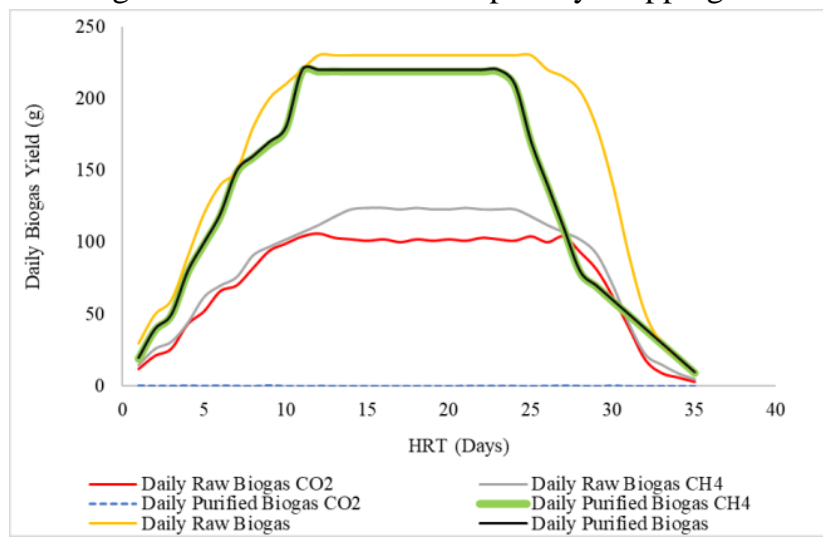

Figure 6. Biogas productivity curve plotted from codigestion of food waste with cow dung

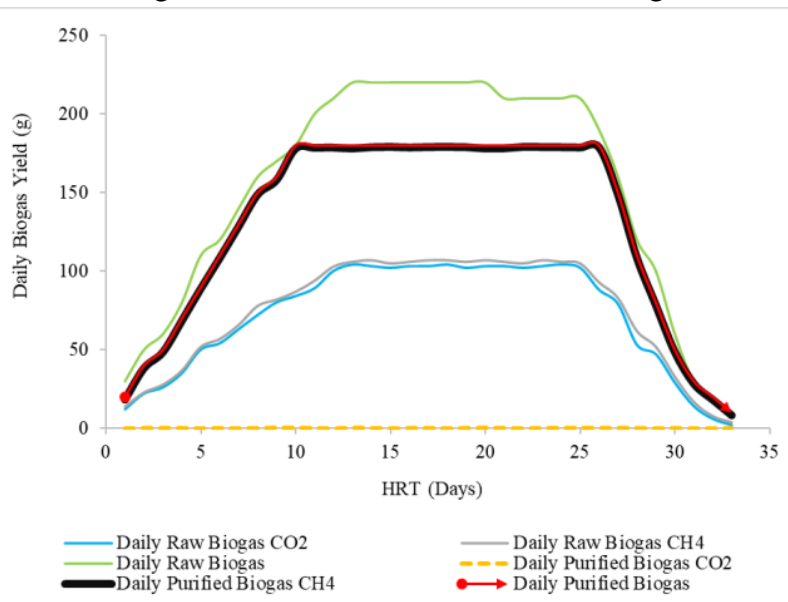

Figure 7. Biogas productivity curve plotted from codigestion of food waste with fruit waste 
Table 2. Co-digestion of food waste with poultry dropping, cow dung and fruit waste

\begin{tabular}{|c|c|c|c|c|c|c|c|c|c|}
\hline \multirow{2}{*}{$\begin{array}{c}\text { HRT } \\
\text { (Days) }\end{array}$} & \multicolumn{3}{|c|}{ Food Waste, Poultry dropping 39kg } & \multicolumn{3}{|c|}{ Cow dung, Food Waste 39kg } & \multicolumn{3}{|c|}{ Fruit, Food Waste 39kg } \\
\hline & Raw Biogas (g) & $\begin{array}{c}\text { Purified } \\
\text { Biogas } \\
\text { (g) }\end{array}$ & $\begin{array}{c}\text { Water } \\
\text { Acidity } \\
\text { Test-pH }\end{array}$ & $\begin{array}{c}\text { Raw } \\
\text { Biogas } \\
\text { (g) }\end{array}$ & $\begin{array}{c}\text { Purified } \\
\text { Biogas } \\
\text { (g) }\end{array}$ & $\begin{array}{c}\text { Water } \\
\text { Acidity } \\
\text { Test-pH }\end{array}$ & $\begin{array}{c}\text { Raw } \\
\text { Biogas } \\
\text { (g) }\end{array}$ & $\begin{array}{c}\text { Purified } \\
\text { Biogas } \\
\text { (g) }\end{array}$ & $\begin{array}{c}\text { Water } \\
\text { Acidity } \\
\text { Test-pH }\end{array}$ \\
\hline 1 & 20 & 10 & 6.4 & 30 & 20 & 6.8 & 30 & 20 & 6.7 \\
\hline 2 & 40 & 30 & 5.3 & 50 & 40 & 5.4 & 50 & 40 & 5.2 \\
\hline 3 & 60 & 40 & 4.2 & 60 & 50 & 4.4 & 60 & 50 & 4.2 \\
\hline 4 & 90 & 50 & 4.1 & 90 & 80 & 4.2 & 80 & 70 & 4.7 \\
\hline 5 & 100 & 70 & 3.9 & 120 & 100 & 4.0 & 110 & 90 & 3.9 \\
\hline 6 & 120 & 90 & 3.4 & 140 & 120 & 4.0 & 120 & 110 & 4.0 \\
\hline 7 & 130 & 100 & 3.2 & 150 & 150 & 3.9 & 140 & 130 & 3.8 \\
\hline 8 & 140 & 120 & 3.3 & 180 & 160 & 3.5 & 160 & 150 & 3.9 \\
\hline 9 & 150 & 150 & 3.4 & 200 & 170 & 3.6 & 170 & 160 & 4.1 \\
\hline 10 & 160 & 160 & 3.3 & 210 & 180 & 3.2 & 180 & 180 & 3.9 \\
\hline 11 & 170 & 160 & 3.2 & 220 & 220 & 3.3 & 200 & 180 & 4.0 \\
\hline 12 & 180 & 160 & 3.4 & 230 & 220 & 3.4 & 210 & 180 & 3.9 \\
\hline 13 & 180 & 160 & 3.3 & 230 & 220 & 3.3 & 220 & 180 & 4.0 \\
\hline 14. & 180 & 160 & 3.4 & 230 & 220 & 3.2 & 220 & 180 & 3.8 \\
\hline 15. & 180 & 160 & 3.6 & 230 & 220 & 3.2 & 220 & 180 & 3.9 \\
\hline 16. & 180 & 160 & 3.3 & 230 & 220 & 3.2 & 220 & 180 & 3.9 \\
\hline 17. & 180 & 160 & 3.5 & 230 & 220 & 3.3 & 220 & 180 & 4.1 \\
\hline 18. & 180 & 160 & 3.4 & 230 & 220 & 3.3 & 220 & 180 & 4.0 \\
\hline 19. & 180 & 160 & 3.6 & 230 & 220 & 3.2 & 220 & 180 & 3.8 \\
\hline 20. & 180 & 160 & 3.3 & 230 & 220 & 3.2 & 220 & 180 & 3.9 \\
\hline 21. & 180 & 160 & 3.3 & 230 & 220 & 3.5 & 210 & 180 & 3.8 \\
\hline 22. & 180 & 160 & 3.3 & 230 & 220 & 3.4 & 210 & 180 & 4.0 \\
\hline 23. & 180 & 160 & 3.3 & 230 & 220 & 3.6 & 210 & 180 & 3.9 \\
\hline 24. & 170 & 160 & 3.2 & 230 & 210 & 3.7 & 210 & 180 & 3.8 \\
\hline 25. & 160 & 150 & 3.7 & 230 & 170 & 3.7 & 210 & 180 & 4.1 \\
\hline 26. & 120 & 140 & 3.9 & 220 & 140 & 3.8 & 190 & 180 & 4.2 \\
\hline 27. & 100 & 130 & 4.1 & 215 & 110 & 3.7 & 160 & 150 & 4.2 \\
\hline 28. & 90 & 90 & 4.1 & 205 & 80 & 3.9 & 120 & 110 & 4.3 \\
\hline 29. & 60 & 60 & 4.2 & 180 & 70 & 3.9 & 100 & 80 & 4.4 \\
\hline 30. & 50 & 40 & 4.3 & 140 & 60 & 4.2 & 60 & 50 & 4.4 \\
\hline 31. & 20 & 20 & 4.4 & 90 & 50 & 4.3 & 30 & 30 & 4.5 \\
\hline 32. & 10 & 10 & 4.6 & 50 & 40 & 4.3 & 20 & 20 & 4.6 \\
\hline 33. & - & - & - & 30 & 30 & 4.4 & 10 & 10 & 4.7 \\
\hline 34. & - & - & - & 20 & 20 & 4.5 & - & - & - \\
\hline 35. & - & - & - & 10 & 10 & 4.8 & - & - & - \\
\hline 36. & - & - & - & - & - & - & - & - & - \\
\hline Total & 4120 & 3700 & - & 5830 & 4920 & - & 5010 & 4330 & - \\
\hline
\end{tabular}

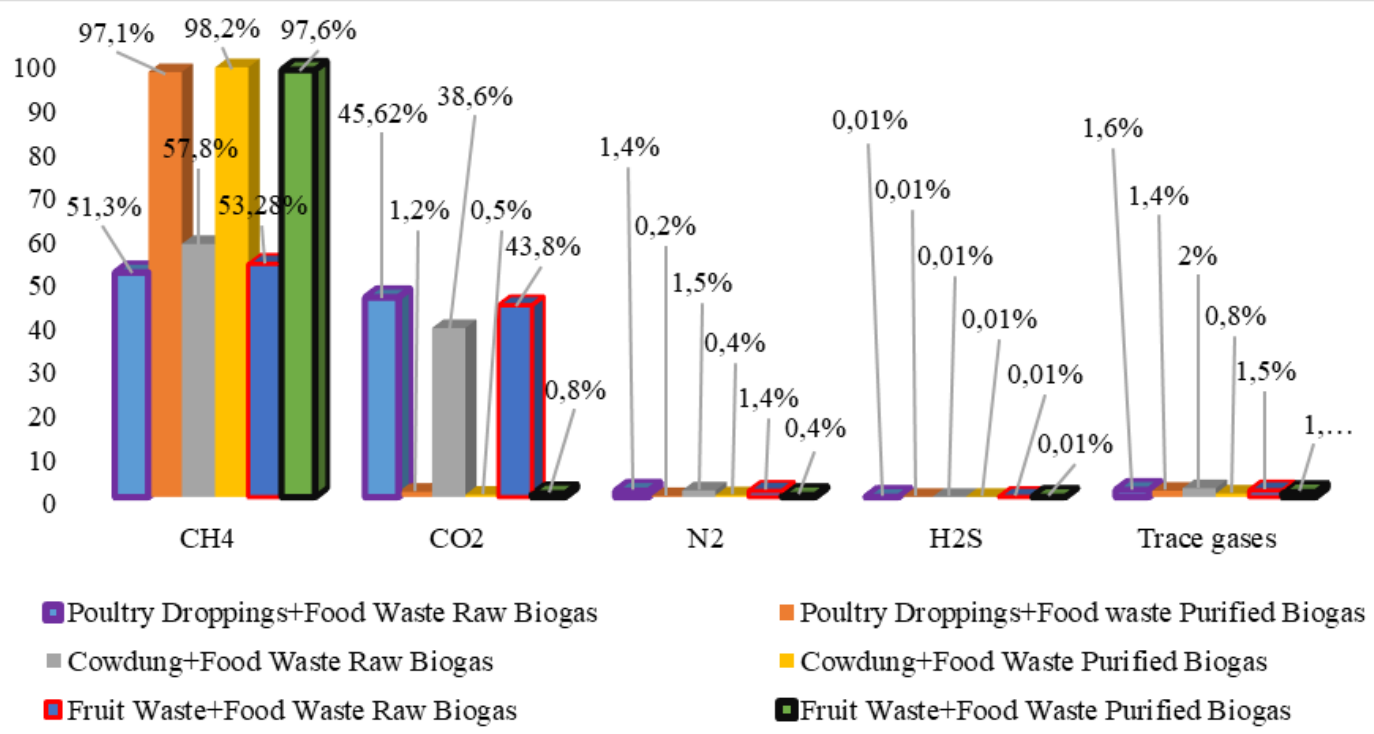

Figure 8. Biogas composition measured with Optima 7 biogas device 


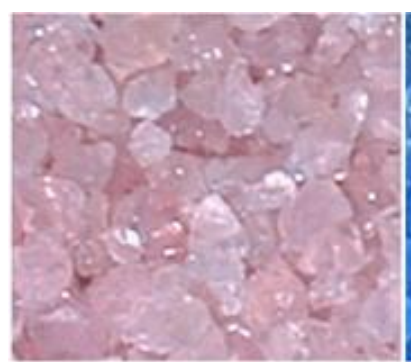

(a) Before reaction with raw biogas

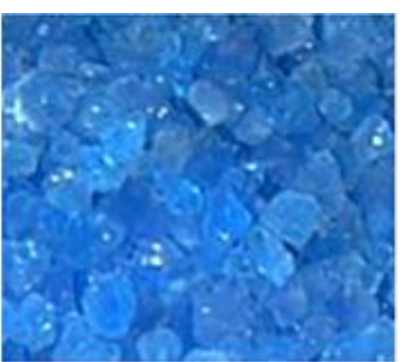

(b) After reaction with raw biogas
Figure 9. Effect of wet biogas on silica gel used as drying agent

The acidity of the water which is categorize as carbonic acid which forms as a result of $\mathrm{CO}_{2}$ interaction with water molecules. Furthermore, water content present in the biogas living the water scrubber vessel entered another scrubber vessel containing Type B crystal pink silica gel and its interaction with water molecules present in the biogas changed its initial color from crystal pink to crystal blue as shown in Figure 9. The biological breakdown of organic materials generated biogas which was channelled through a scrubbing until containing distilled water, and carbon dioxide content in the biogas dissolved within the water molecules to forms carbonic acid $\left(\mathrm{H}_{2} \mathrm{CO}_{3}\right)$ which produced slightly sour test similar to soda drinks and carbonated water. During the water and carbon di oxide reaction, Carbonic acid may lose protons to form bicarbonate $\left(\mathrm{HCO}_{3}{ }^{-}\right)$and carbonate $\left(\mathrm{CO}_{3}{ }^{2-}\right)$. In this case the proton is liberated to the water and thus, $\mathrm{pH}$ of the water is decreased. Relative, $\mathrm{H}_{2} \mathrm{CO}_{3}$ concentration is actually $\mathrm{CO}_{2}$ in equilibrium with water. The chemical reaction between $\mathrm{CO}_{2}$ and $\mathrm{H}_{2} \mathrm{O}$ can be expressed as;

$$
\mathrm{CO}_{2}+\mathrm{H}_{2} \mathrm{O} \rightarrow \mathrm{H}_{2} \mathrm{CO}_{3}
$$

or

$$
\mathrm{CO}_{2}+\mathrm{H}_{2} \mathrm{O} \rightarrow \mathrm{HCO}_{3^{-}}+\mathrm{H}^{+}
$$

The moles of $\mathrm{CH}_{4}$ and $\mathrm{CO}_{2}$ can be determined from the stoichiometric reaction stated in equation (6), and can be converted into masses from the molecular weight of 16 and $44 \mathrm{~g} / \mathrm{mol}$.

\section{Conclusion}

Anaerobic digestion of organic substrate is a proven technology for processing source-separated organic wastes and its application has increased significantly in recent times, particularly in the area of biogas production. The result has shown that co-digestion of food waste with other organic substrates such as animal excrements can yield more biogas than the process where only one type of substrate is digested for biogas production. The result has also shown that the concentration of carbon dioxide in biogas production is dominant, and could interact with other gases present in biogas to form acidic compounds or gases which depending on the toxicity could have negative effects on public health and environment. This observation was conspicuous in the Water Acidity Test, where $\mathrm{pH}$ of the water dropped significantly from 7-3.2, indicating the presence of carbonic acid. This however necessitates proper purification of biogas before usage. However, co-digestion of food waste with cow dung which produced the highest amount of raw biogas of $5010 \mathrm{~g}$ and purified biogas of $4330 \mathrm{~g}$ also had the longest HRT of 35 days. In addition, the amount of raw biogas reduced significantly after purification.

\section{References}

[1] http://www.dandc.eu/en/article/benins-energy-supplydepends-fire-wood-and-smuggled-petrol-nigeria

[2] http://www.groundtruthtrekking.org/Issues/OtherIssues/ True-Cost-Electricty-Generation.html

[3] Adamu, C. O., Alarima, C. I., 2013, "Perceived Effect of Fuelwood Utilization on Climate Change by Rural Dwellers in Northwestern Nigeria", American Journal of Human Ecology, 2(2), 54-59.

[4] Ikpe A., Owunna I., 2016, "Review of Municipal Solid Waste Management Technologies and Its Practices In China And Germany", International Journal of Technology Enhancements and Emerging Engineering Research, 4(5), 1-7.

[5] Otun, T. F., Ojo, O. M., Ajibade, F. O., Babatola, J. O., 2015, "Evaluation of Biogas Production From The Digestion And Co-digestion Of Animal Waste, Food Waste And Fruit Waste", International Journal of Energy and Environmental Research, 3(3), 12-24.

[6] Ukpabi, C., Ndukwe, O., Okoro, O., John, I., Eti, P., 2017, "The Production of Biogas Using Cow Dung and Food Waste", International Journal of Materials and Chemistry, 7(2), 21-24.

[7] Ukwuaba, S. I., 2018, "Performance Evaluation of Biogas Yields Potential from Co-Digestion of Water Hyacinth and Kitchen Waste", European Journal of Engineering Research and Sciences, 3(4), 36-39.

[8] Leta, D., Solomon, L., Chavan, R. B., Daniel, M., Anbessa, D., 2015, "Production of Biogas from Fruit and Vegetable Wastes Mixed with Different Wastes", Environment and Ecology Research, 3(3), 65-71.

[9] Olmedo, C., Gomez, A., Cartagena, R., 2014, "Energetic performance of landfill and digester biogas in a domestic cooker" Journal of Applied Energy, 134, 301 308.

[10] NSDBS National Standard of the People's Republic of China on Domestic Biogas Stove: GB/T 3606-2001, 2001, State General Administration of Quality Supervision and Inspection and Quarantine of the People's of Republic of China (AQSIQ), No. 9, Madian Donglu Haidian, District Beijing, 100088, People's Republic of China.

[11] Bureau of Indian Standards, 2002 "Biogas stovespecification, second revision", Bureau of Indian 
Standards, BIS: IS 8749: 2002, Manak Bhavan, New Delhi, India.

[12] Orhorhoro, E. K., Ebunilo, P. O., Tamuno, R. I., Essienubong, I. A., 2016, The Study of Anaerobic CoDigestion of Non-Uniform Multiple Feed Stock Availability and Composition in Nigeria, European Journal of Engineering Research and Science, 1(1), 14.

[13] http://www.toolkit.bc.ca/success-story/hartlandlandfill-gas-utilization-project

[14] http://www.big-eu/info_biogas.html

[15] Lijun, Z., Jiancheng, S., Chuanyang, L., Yunguang, G., Pulong, G., Binni, Q., Linyan, L., 2014, "Preferential policies promote municipal solid waste (MSW) to energy in China: Current status and prospects" Journal of Renewable and Sustainable Energy Reviews, 36,135-148.

[16] Spence, A., 2017, "Evaluation of Anaerobic Digestibility of Energy Crops and Agricultural Byproducts", School of Water, Energy and Environment, Cranfield University.

[17] Seadi, T., Rutz, D., Prassl, H., Kottner, M., Finsterwalder, T., Volk, S. Janssen, R., 2008, "Biogas Handbook", University of Southern Denmark Esbjerg, Niels Bohrs Vej 9-10, DK-6700 Esbjerg, Denmark.

[18] Rawson, M., Sethi, P., Spiegel, L., Hope, L., Oglesby, R., 2012, "Removal of Siloxane and H2s from Biogas using Microwave Energy" Sacramento Municipal Utility District, North California, California Energy Commission.

[19] Arnold, M., 2009, Reduction and monitoring of biogas trace compounds. VTT, Vuorimiehentie 3, PL 1000, 02044 VTT and VTT, Bergsmansvagen 3, PB 1000, 02044 VTT, Finland.

[20] http://www.methanetomarkets.org/partners/nigeria.aspx

\begin{tabular}{|c|c|}
\hline \multicolumn{2}{|r|}{ Nomenclature } \\
\hline $\mathrm{A}_{\mathrm{c}}$ & Ionized acetate concentration \\
\hline $\mathrm{C}$ & Circumference of Digester \\
\hline $\mathrm{CH}_{4}$ & Methane \\
\hline $\mathrm{Cm}^{3}$ & Centimetres Cube \\
\hline $\mathrm{CO}_{2}$ & Carbon dioxide \\
\hline $\mathrm{CO}_{3}^{2-}$ & Carbonate \\
\hline D & Diameter of Digester \\
\hline $\mathrm{g}$ & gram \\
\hline $\mathrm{g} / \mathrm{mol}$ & gram per mole \\
\hline GHG & Green House Gas \\
\hline$h$ & Height of Digester \\
\hline $\mathrm{H}_{2}$ & Hydrogen \\
\hline $\mathrm{HCO}_{3}{ }^{-}$ & bicarbonate \\
\hline $\mathrm{H}_{2} \mathrm{CO}_{3}$ & Carbonic acid \\
\hline $\mathrm{H}_{2} \mathrm{O}$ & Water \\
\hline $\mathrm{H}_{2} \mathrm{~S}$ & Hydrogen Sulphide \\
\hline HTR & Hydraulic Retention Time \\
\hline ICE & Internal Combustion Engines \\
\hline IR & Infrared \\
\hline $\mathrm{K}_{\mathrm{a}}$ & Dissociation constant for acetate \\
\hline $\mathrm{Kg}$ & Kilogram \\
\hline $\mathrm{K}_{\mathrm{im}}$ & Inhibition constant of acetate on methane yield \\
\hline $\mathrm{K}_{\mathrm{m}}$ & Saturation constant of methane yield \\
\hline KWh & Kilowatt hour \\
\hline MSW & Municipal Solid Waste \\
\hline MMTCE & Million Metric Tons of Carbon Equivalent \\
\hline MWh & Megawatt hour \\
\hline $\mathrm{pH}$ & Potential of Hydrogen \\
\hline$\pi$ & $\mathrm{Pi}$ \\
\hline$r$ & Radius of Digester \\
\hline $\mathrm{V}$ & Volume of Digester \\
\hline $\mathrm{Vm}_{\max }$ & $\begin{array}{l}\text { Maximum yield rate of methane per gram of } \\
\text { methanogenic bacteria per day }\end{array}$ \\
\hline$X_{m}$ & Methanogenic food waste substrate \\
\hline
\end{tabular}

